\title{
IHTEPB'Ю
}

\section{ІНТЕРВ'Ю ДОКТОРА С.-Г. НАУК, ЗАВІДУВАЧА ВІДДІЛУ РОСЛИННИЦТВА ТА НЕПОЛИВНОГО ЗЕМЛЕРОБСТВА ІНСТИТУТУ ЗРОШУВАНОГО ЗЕМЛЕРОБСТВА НАЦІОНАЛЬНОЇ АКАДЕМІЇ АГРАРНИХ НАУК УКРАЇНИ ЗАЙЦЯ С.О. ОСОБЛИВОСТІ СІВБИ ТА РОЗВИТКУ ОЗИМИХ КУЛЬТУР ЗАЛЕЖНО ВІД АГРОМЕТЕОРОЛОГІЧНИХ УМОВ ОСІННЬОГО ПЕРІОДУ 2021 РОКУ}

Проблема збільшення виробництва продовольчого зерна $€$ однією з найважливіших народногосподарчих задач країни. Без повного ії̈ вирішення неможливо забезпечити зростаючи потреби країни та світового ринку в продовольчому зерні.

У збільшенні виробництва зерна основна роль належить озимим зерновим культурам. Крім того, що південь України є однією з важливих зон у виробництві зерна, він ще й займає провідне місце у вирощуванні найбільш цінної зернової культури - пшениці озимої.

Відомо, що осінній період для виробництва зерна як для пшениці озимої, так і для інших озимих зернових культур завжди $є$ відповідальним, оскільки безпосередньо в цей період закладаються основи майбутнього врожаю.

Однак характерною кліматичною особливістю зони Південного Степу є посушливість, часті роки з недостатньою кількістю опадів. Спостерігаються тривалі періоди ґрунтових і повітряних посух, що не дозволяють отримувати своєчасні і повноцінні сходи та нормальний розвиток рослин.

А які ж агрометеорологічні умови спостерігались у передпосівний та післяпосівний періоди озимих культур цього року?

У цьому році, як і в попередні роки, на більшій частині території Південного Степу спостерігалися складні погодні умови літнього періоду, особливо другої його половини. Так, у цей період, за даними Херсонського обласного центру з гідрометеорології, спостерігались високі температури повітря до $33-36{ }^{\circ} \mathrm{C}$, а поверхня ґрунту нагрівалась до 59-63 ${ }^{\circ} \mathrm{C}$ тепла, що разом із тривалим періодом без продуктивних опадів призвело до утворення повітряно-ґрунтової посухи та їх поширення і поглиблення.

Тому на початку вересня у господарствах Херсонської області на більшій частині площ після непарових попередників продуктивні запаси вологи в посівному шарі ґрунту (0-10 см) були дуже низькими 1-7 мм, а в південно-західних та південно-східних районах - вичерпані повністю. Це негативно позначилось на підготовці ґрунту, своєчасній сівбі та отримання сходів. Лише в окремих господарствах півночі та південного сходу області, де локально пройшли дощі, запаси вологи дозволяли отримати сходи.

У цілому агрометеорологічні умови перших двох місяців осені залишались малосприятливими для проведення сівби, а також для початкового росту та розвитку вже посіяних озимих зернових культур. Більшість площ після непарових попередників була засіяна у сухий Ґрунт, і насіння в ньому залишалось не пророслим протягом 25-30 діб. Кількість опадів у вересні і жовтні на більшій частині території Херсонської області складала 10-16 та 2-9 мм (29-47 і 7-27\% місячної норми), а на південному сході - 59 та 10-14 мм (184 і 34-45\% місячної норми). Проте вітряна погода висушувала верхні шари ґрунту, а відсутність продуктивних опадів негативно позначились на його зволоженні. Так, станом на кінець жовтня запаси продуктивної вологи під пшеницею озимою в орному шарі ґрунту (0-20 см) на більшій частині території Херсонської області сформувались на дуже низькому рівні - 2-3 мм, лише у південно-східних районах та на зрошенні відповідали задовільним показникам - 18-22 мм.

Агрометеорологічні умови протягом листопада для осіннього розвитку озимих культур складались задовільно, спостерігався помірно теплий температурний режим, а кількість опадів становила 33-49 мм (83-135\% місячної норми).

Порівняно з минулими роками осінній період цього року яким був?

Якщо аналізувати весь осінній період цього року, то виявлено, що середня добова температура повітря знаходилась у межах середньої багаторічної норми, але на $3{ }^{\circ} \mathrm{C}$ нижче торішньої. За даними Херсонського обласного центру з гідрометеорології, подібний температурний режим відмічався восени 2013 року, а середня кількість опадів за календарну осінь 2021 року склала 70 мм, що на 33 мм менше середньої багаторічної норми та на 22 мм менше, ніж за осінь 2020 року. Порівняно з попередніми роками кількість вологи в ґрунті у кінці жовтня була меншою, ніж у 2019 і 2020 рр., та близькою - в 2017 та 2018 рр.

Який вплив спричинили такі погодні умови на ростові процеси озимих культур?

Посіви пшениці озимої знаходяться в різновіковому стані розвитку - від формування 2-3 листків до утворення 2-5 пагонів (рис.1-2).

Посіви пшениці озимої залежно від строків сівби, мінерального та вологозабезпечення на більшості площ знаходяться в задовільному та доброму стані. На полях, де з осені не вносили добрива, відмічається пожовтіння листків та відставання в рості, що є ознакою азотного голодування рослин.

Місцями, особливо на ранніх та добре розвинених посівах пшениці озимої, спостерігаються грибні хвороби (кореневі гнилі, септоріоз) та ушкодження злаковими 
мухами та іншими сисними комахами і кліщем. На озимині після стерньового попередника відмічається наявність хлібного туруна, а на всіх посівах - мишевидні гризуни.

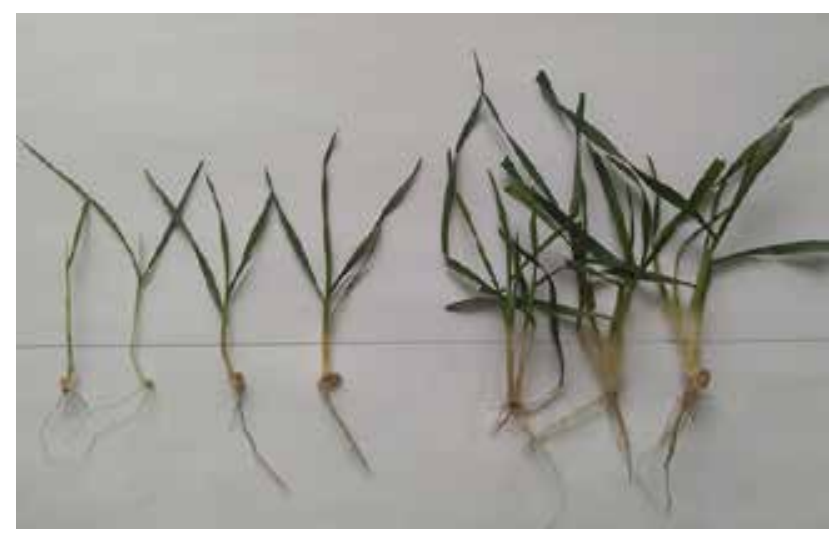

Рис. 1. Стан розвитку рослин пшениці озимої після ріпаку озимого в неполивних умовах (1-4 рослина $з$ ліва на право) та на зрошенні (5-7 рослина) перед припиненням осінньої вегетації (17.12.2021 р.)

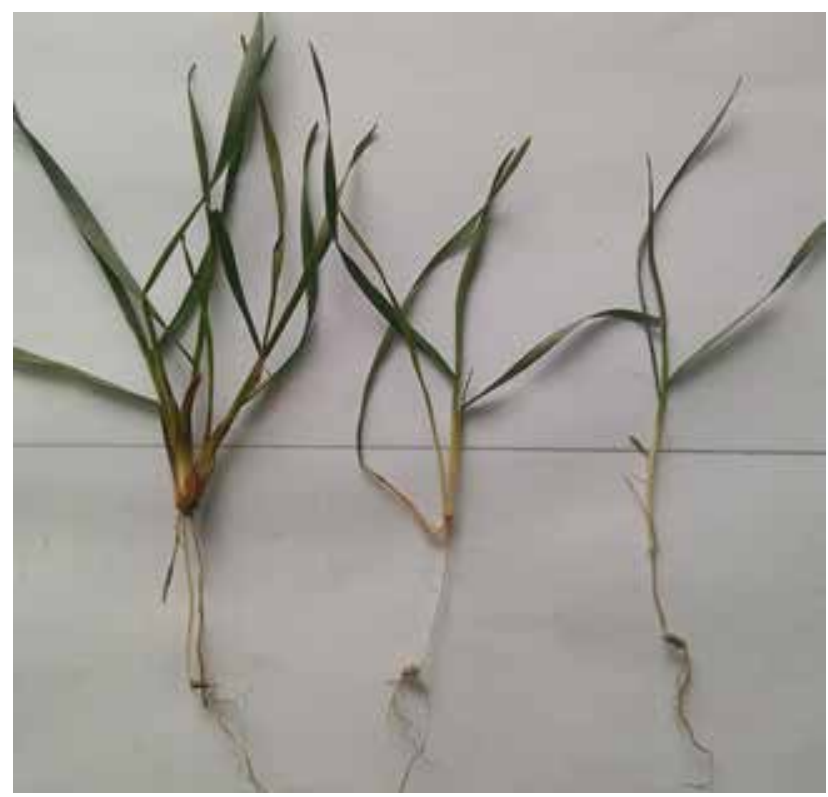

Рис. 2. Стан розвитку рослин пиениці озимої по пару за сівби 1, 10 і 20 жовтня (зліва на право)

Стан посівів ячменю озимого дещо гірший, його рослини менш розвинені, ніж пшениці, що пов'язано з сівбою в пізніші терміни та після гірших попередників. Фази розвитку рослин - від формування 1-3 листків до утворення 2-4 пагонів (рис. 3).

Більшість посівів ячменю озимого мають слабкий та зріджений стан.

Рослини ріпаку озимого сформували розетку 3 5-15 листків залежно від строку сівби і волого забезпечення попередників. На полях, де низькі запаси вологи в ґрунті та не вносили мінеральні добрива, рослини мають фрілетове забарвлення та значно відстають у рості. Посіви ріпаку озимого по пару надмірно розвинені і в господарствах для гальмування ростових про- цесів рослини обприскували інгібіторами росту, а також проводилась боротьба зі шкідниками.

Слід відмітити, що в першій половині третьої декади листопада озимі культури перебували у стані нестійкого зимового спокою, а з 26 листопада, внаслідок підвищеного температурного режиму, відновили ростові процеси. У найхолодніші дні температура ґрунту на глибині залягання вузла кущіння пшениці озимої знижувалась від $0^{\circ}$ до $2{ }^{\circ} \mathrm{C}$ морозу, що не завдало шкоди рослинам усіх озимих культур.

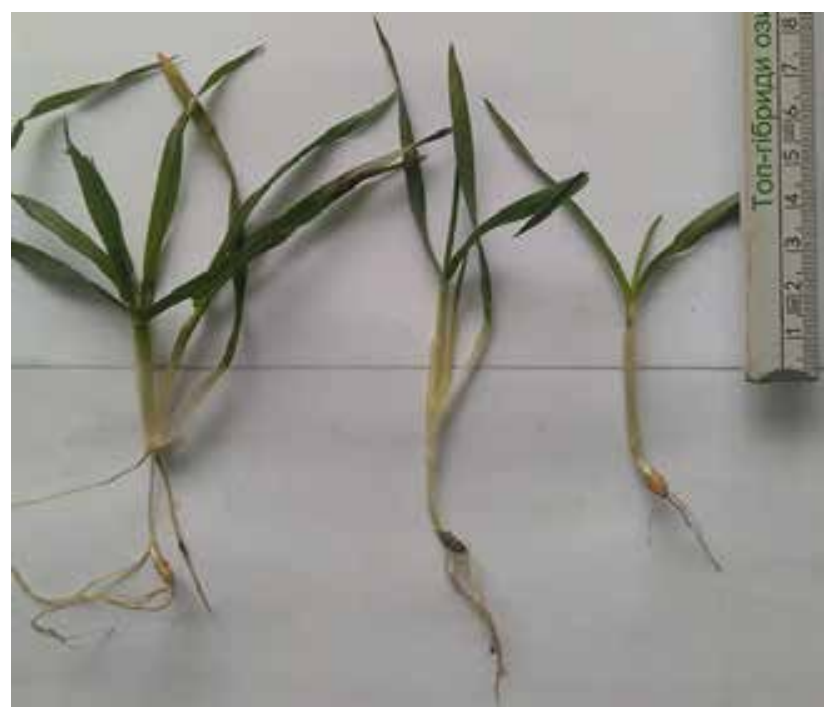

Рис. 3. Стан розвитку рослин ячменю озимого по пару за сівби 1, 10 і 20 жовтня (зліва на право)

Проте агрометеорологічні умови листопада і першої половини грудня сприяли ростовим процесам озимих культур, а там, де насіння раніше знаходилось в сухому ґрунті, відбулося його проростанню та поява сходів. Волога та тепла, як для початку календарної зими, погода позитивно впливала на стан рослин, а на посівах пізніх строків сівби спостерігалась зміна фразового розвитку. Проте такі погодні умови не сприяли загартуванню рослин. У середині грудня озимі культури увійшли в стан зимового спокою.

Як оцінити підготовку озимих зернових культур до перезимівлі?

В основі наукових уявлень про природу морозостійкості рослин лежить теорія загартування та накопичення вуглеводів у вузлах кущення рослин озимих зернових культур. Уміст розчинних вуглеводів (цукрів) у тканинах вузла кущення на час припинення осінньої вегетації дає змогу встановити потенційну здатність рослин протистояти несприятливим умовам перезимівлі. За агрометеорологічних умов цього року не відбувалось доброго загартування рослин, на час припинення осінньої вегетації у вузлах кущення пшениці озимої накопичилось в середньому $33,60 \%$ цукрів з максимальною їх кількістю 37,54\%, що відповідно на 11,51 і 11,78\% менше, ніж у минулому році. Значно менше цукрів накопичили рослини ячменю озимого - у середньому $17,62 \%$ з максимальним вмістом 22,34\%. Восени минулого року їх вміст був значно більшим і складав 38,50-43,52\%. 
Для нормальної перезимівлі озимих культур у період осіннього загартування рослин вміст цукрів у вузлах кущення повинен становити 32-35\%. Такий або близький вміст цукрів накопичили рослини пшениці озимої, а ось рослини ячменю озимого мають понижену стійкість до несприятливих агрометеорологічних умов: низьких від'ємних температур повітря та різких їх коливань, відсутності снігового покриву, відлиг, льодяної кірки, видування, вимокання, випрівання, а також весняних заморозків.
Також слід врахувати те, що в умовах цього року ґрунт на значній частині площ був сухий, мікробіологічні процеси в ньому не відбувалися і доступні форми поживних речовин не утворювалися, а деякі господарства не проводили до та після посівного внесення мінеральних добрив, то слід передбачити підживлення посівів ними рано навесні до відновлення весняної вегетації. За оптимального вологозабезпечення озимих культур таке підживлення азотними добривами підвищує врожайність зерна на 0,9-1,3 т/га та покращує його якість. 